\title{
BETWEEN GOOD AND EVIL... A NURSING HOME AND THE NEEDS AND EXPECTATIONS OF INHABITANTS AND THEIR FAMILIES
}

\begin{abstract}
Human history is situated between good and evil. The reflection concerns the complex reality of meeting inhabitants' needs in an institution being a nursing home. A stay at a nursing home is necessary in crisis situations with which a family or an individual cannot deal themselves. A nursing home is a home for its inhabitants who have specific requirements. For the purposes of the article, interviews were conducted with the personnel and management of two nursing homes for the elderly. Conclusions indicate the need for individualised help and care for residents.
\end{abstract}

KEYWORDS: ethics of care, nursing home, social welfare institution, family, relativism, needs, old age

\section{A NURSING HOME AS AN INSTITUTION}

Social aid became one of the main functions of society, replacing family solidarity and charity dictated by religion. Welfare institutions are established in order to meet social needs, which cannot be met independently by an individual or their family. In the contemporary world help given by people has been replaced by an institutional system. There have been changes towards specialisation and professionalization of the institution so as to meet specific needs of recipients. Professional help, 
understood as providing services for remuneration, is given according to specific rules, on the grounds of an official contract, which makes it different from spontaneous, direct help. However, this character of help is not released from the necessity to establish relations. Nevertheless, as noticed by Ewa Wysocka, there is a discord in professional relation of giving help consisting in internal discrepancy originating from a meeting of two entities, where one is the subject of work performed by the other. In this case, in the relation of giving help it is difficult to establish and deepen emotional connection, closeness, true and open contact between people, since there is no possibility to develop this relationship. It is limited in time and one-sided. The difficulty of this relation consists in the fact that this is a formal relation that, at the same time, is a meeting of two people in a situation of help, which, irrespectively of the character thereof, is always accompanied by "some" emotions (Wysocka 1998, p. 477).

The individual approach to institutional help is diverse, as it is determined with environmental conditions, in which the individual lives, but also the whole baggage of experiences gained throughout life.

While reflecting on the effects of access to various types of help, E. Wysocka underlined the ambivalence in the assessment of this process. Depending on the assessment criteria, it is a positive and, at the same time, negative phenomenon. Considering the criterion of effectiveness and responsibility with regard to the needs, the mutual help provided by natural social groups has been assessed positively by the author. This assessment comprises effectiveness of help, overcoming isolation and loneliness of individuals, elimination of anonymity and attitudes of indifference in social relations, establishing social relationships, which, in consequence, leads to rebuilding the community. Considering the criterion of knowledge and skills (professionalization) in the scope of help, the author assessed the system of public institutions as fulfilling the tasks of providing aid (when all pathological behaviours in this area are discarded) (1998, pp. 470-471).

Nonetheless, nursery homes for the elderly remain a socially sensitive topic for the family, the inhabitant and the public opinion. Social receipt of this type of institution has an ambivalent character; on the one hand, 
those institutions are more and more needed as a result of demographic and cultural changes occurring in a family, perceived as the best solution in a situation of an illness, disability and loneliness. On the other hand, in the Polish society people still believe in the tragic fate of persons who have to stay in nursery homes. Such an opinion results to a great extent from the beliefs passed on in families and educational institutions concerning the family's obligations towards its members.

\section{FAMILY CONDITIONS OF TAKING A DECISION ON PLACING ITS MEMBER IN A NURSERY HOME}

An important aspect of perceiving social aid constitutes changes occurring in family structures and functions. In the most general manner, one can discuss transformation of a family on the grounds of three basic models: a traditional, modern and post-modern family. While analysing their development and characteristics, one must notice the changes occurring in the area of relations between family members, which are gradually undergoing democratisation, humanisation and empowerment, whereas, at the same time aiming for individualisation, egoism, loosening relationships or even chaos. The aforementioned family models were established and developed in different socio-cultural conditions with different value systems and culture of interpersonal relations. The possibilities of family members' cooperation were changing, since as a result of cultural changes, their social position also changed (Doniec 2009, pp. 153-156).

The family, apart from social features defining it in terms of organisation and generation, is also a network of mutual expectations, resulting from this organisation, conditioning the manner in which family members interact. A family as a social unit is based on the relations among individuals, this relationship is a basic condition of a family's existence. Its frame comprises moral feelings which generate the sense of obligation. Each family develops its own system of mutual relations, repeated and reinforced in a form of patterns of behaviours towards particular members. Those patterns of interactions regulate the behaviours of family members depending on the held position and, at the same time, become models of its members' 
behaviours relevant only for a given family (de Barbaro 1999, p. 47). One of the most important features and, at the same time, the most desirable in families, is loyalty. Family loyalty results from group expectations with which all members are obliged, it is manifested with mutual trust, recognition of mutual merits, obligations, honesty (Kołbik 1999, p. 79). Therefore, it is a characteristic feature of family relations. Thus, it cannot be assumed that family members' behaviours have no significance, especially in a relation between children and parents, as they are often perceived as a form of gratitude or a lack thereof. "A relation between a child and a parent becomes the last, inseparable and not subject to exchange, primary social relationship. Partners come and go. A child stays." (Beck 2004, p. 181). A family loyalty is related to the sense of guilt, which becomes a driver of family relations. According to I. Kołbik, a sense of guilt results from a misunderstanding in perception of mutual obligations, but it is also a mechanism that has an attribute of introducing balance to the family system (1999, p. 78). In consequence, the sense of guilt leads to the stability of norms and values followed in a given family. The sense of guilt to a large extent results in the attitude towards aid institutions, as well as the family's attitude to possible placement of its member in an aid institution.

In a family, relations develop a communication system based on direct, intimate and personal contact covering the whole scope of human life. These contacts are emotional, intensive, frequent and long-lasting. Through everyday relations a family is establishing relationships, implements values, applies norms in everyday life, but all of this happens spontaneously, the everyday life is determined by habits, customs, rituals, emotions and impulses, therefore, a family is rarely rational with clearly defined aims and means of operation. Family members have to work to its benefit, create, care, build and maintain atmosphere, climate favouring good coexistence, cooperation, impartial collaboration to the benefit of its members (Dyczewski 1994, pp. 105-118; Turowski 1998, pp. 11-18).

In the crisis situation the context of duty and obligations towards family members is especially important, primarily in a situation, when it is necessary to use a welfare institution being a nursery home. In these circumstances, the sense of guilt is especially acute. Children loyal to parents and family, 
in which they were growing up, strive to meet the obligations. They believe they owe care and aid to parents, they notice the duty of reciprocation. The sense of children's duty towards parents is definitely noticeable in a situation of a need, yet, foreseen by both generations and expected by the elder (GuzySteinke 2014).

Are nursery homes a good solution for a family? Is it a good solution for residents?

These are difficult questions and answers thereto are surely not unambiguous. While answering thus formulated questions and, at the same time, referring to previous reflections regarding family, one may refer to moral relativism. The word "relativism" is sometimes uses to define the phenomenon of discretion in applying or rejecting moral norms depending on the current situation and own convenience. Whereas, relativism does not refer to an individual at all.

As written by Julian Baggini and Peter Fosl in "The Ethics Toolkit: A Compendium of Ethical Concepts and Methods" (2010): In the broadest understanding, an ethical relativist is anyone who rejects the opinion that moral principles and rules are absolute and common, that is, they refer to all people, at any time and place. We should note that there is no contradiction in the statement that relativism in itself is absolutely and commonly true. Ethical relativists do not have to believe that everything is relative, but only that moral principles and rules are relative. The moral judgment relativism assumes that moral judgements are relative and depend on persons, groups and circumstances. Relativism sees the source of moral principles in a human, treats normative systems as a type of social agreement and moral norms are subject to changes over the years. Relativism demands recognition that other people also have their value systems and that a human should limit his or her freedom due to others. Relativism takes into consideration conflicts of value, which are very important from the point of view of a contemporary human and unavoidable in the social functioning in a group. In the context of thus understood ethical relativism, the opinion concerning placing a parent or a family member in a nursing home is relative, as it depends on many conditions and circumstances of the family's everyday life, crisis situation, competences of the family members in the scope of aid. 


\section{REALIZATION OF NEEDS AND EXPECTATIONS OF NURSING HOMES' INHABITANTS}

In August and September 2019, a research was conducted in three nursing homes for the elderly in the vicinity of Bydgoszcz and Torun ${ }^{1}$. The research was conducted in two stages. In the first stage the management of the institutions and their staff were informed about the purpose of the research. There were also carried out conversations with nursing homes' residents, who had given their consent. The second stage of the research lasted three weeks, during which in-depth interviews were conducted with 10 carers and 4 social workers, as well as with the management of one of the institutions. The criterion for the selection of respondents was the work period in nursing homes. Employees with over five years of work experience in institutions were interviewed. The interviews concerned observed changes in expectations of family and inhabitants towards the institution over five years. The respondents were also asked to share their reflections on the behaviour of residents towards their roommates as well as towards the staff. They spoke about their own perceptions of their charges, observed needs, longings, fears and joys. All respondents were consistent in the description of the expectations of the family and residents regarding nursing homes.

\section{Table 1. Family's expectations towards a nursing home}

\begin{tabular}{|c|c|c|}
\hline No. & 5 years ago & Currently \\
\hline 1. & 24-hour healthcare & Healthcare \\
\hline 2. & & Catering \\
\hline 3. & & Maintaining hygiene \\
\hline 4. & & Number of persons in one room \\
\hline 5. & & General housing conditions \\
\hline 6. & & Home aesthetics \\
\hline
\end{tabular}

Source: own elaboration

According to carers, in the past, families of nursing homes' residents primarily expected proper healthcare they could not have provided at their family homes. Currently, apart from healthcare family members of welfare 
institutions' inhabitants pay attention to many factors influencing the residents' life satisfaction, among which also the aesthetics of surroundings is mentioned, which, as it turns out, is important for contemporary customers.

Furthermore, apart from healthcare and catering, a very important element of life for the elderly, housing conditions and aesthetic surroundings are significant for inhabitants of nursing homes.

Table 2. Expectations of nursing homes' inhabitants towards the institution

\begin{tabular}{|c|c|c|}
\hline No. & $\mathbf{5}$ years ago & Currently \\
\hline 1. & Healthcare & Catering \\
\hline 2. & Catering & Healthcare \\
\hline 3. & Possibility of visits & Number of persons in one room \\
\hline 4. & & Housing conditions \\
\hline 5. & & Aesthetics of the institution \\
\hline
\end{tabular}

Source: own elaboration

The nursing homes' personnel underline that residents used to primarily pay attention to issues such as 24-hour care and nursing, as well as activation predominantly consisting in therapy and rehabilitation to manage free time.

According to the personnel and management, the value for a resident primarily consists in health and thus, healthcare offered in the institution. Moreover, family, that is, the possibility of contact and visits of the loved ones, the possibility of practising religion, as well as relations with other inhabitants, including, primarily contacts with peers were important for inhabitants; therefore, the positive aspect of staying at a nursing home has been underlined.

The indicated advantages of nursing homes are balanced with negative feelings related to staying at a facility. According to personnel, what is especially bad is that inhabitants found themselves in this institution, which in the Polish society is still assessed/characterised negatively. The behaviour of a family who left or gave a senior to an institution, which resulted in separation from the life lived so far and, in consequence, the necessity to live with strangers - "ill", "other", "weird", is perceived negatively. Among the 
nursing homes' inhabitants "loneliness among people" is dominant, which is noticed by the carers, and which in consequence, in their opinion, leads to the feeling of exclusion, being lost and longing.

In this situation the nursing homes' personnel underlines the need for an individual approach to residents, not directly verbalised by the inhabitants, but noticeable. Every inhabitant seeks a possibility of contact with employees, uses any opportunity to start a conversation, tell a story of their lives. Meanwhile, employees of the institution do not have the time for individual conversations with inhabitants. It is mainly caused by the small number of personnel, a lot of tasks to perform (hygiene, healthcare) that are subject to assessment by superiors, as well as inhabitants themselves and their families. Moreover, as underlined by carers themselves, they are not prepared to establish relationships with inhabitants. The lack of social competences to a great extent hinders performance of their work among older, lonely and lost persons.

The aid institution, that is, the nursing home does not have sufficient possibilities of meeting/satisfying the needs of their inhabitants. Individual needs are disregarded; the need for a conversation, interest or sexual needs. These institutions lack individuality and intimacy. There is a common social belief that sexual needs are suppressed in old age. Whereas, the character of these needs changes. In old age sexual needs occur with diverse, decreased intensity, however, they should not be underestimated. Therefore, there is a need for intimate rooms available to inhabitants in aid institutions.

Shortcomings in the scope of satisfying the need for intimacy and individuality result in growing conflicts, suppressing needs, withdrawal and eventually, indifference. As stated by Aleksander Kamiński, the elderly should be given a reason for living, whereas, the willingness to live is taken away from nursing homes' residents. It so happens, because the technical side of care is underlined in the care provided to older inhabitants of nursing homes, whereas, residents also expect soft competences of the personnel, which are completely omitted in the carers' education. I. Kropińska distinguished instrumental and expressive basics among medical personnel (Bydgoszcz 2000). Expressive attitudes are very desirable in working with people, since they give the possibility of viewing a patient 
in the framework of diverse human needs, not only physiological. The need for the interpersonal communication skills is noticed by the carers working in nursing homes.

\section{AND WHAT'S NEXT?}

The change in the approach to meeting the needs of nursing homes' inhabitants is the more recommended, the more the social reality is changing. The research conducted by B. Szatur-Jaworska concerning the Polish society of the first decade of the $21^{\text {st }}$ century characterises the generation of the oldest Poles. The research showed that the elderly provided a relatively low assessment of their own social position, as they felt they were second-class citizens due to the policy of the government. They perceived themselves to be at the bottom of "the social ladder", which was caused by a relatively low level of education and the fact that the majority of them belonged to the less qualified socio-professional categories. The low perception of their own position also influences the subjectively low sense of a worse financial situation (Szatur-Jaworska 2014, pp. 29-43). Whereas, the research conducted by the Public Opinion Research Center (CBOS) in 2016 "Seniors vs younger generation - problems of the everyday life" indicated that the situation of the elderly $(60+)$ in the scope of finances, a lack of nutrition, access to a doctor does not differ from the situation of younger generations (Kalka 2016, pp. 6-7).

B. Szatur-Jaworska noticed that Poles age prematurely, become disabled prematurely, suffer from depression more often (research: PolSenior 2016) and with years the sense of loneliness becomes more acute (Kalka 2016, p. 8).

As rightly noticed by $B$. Szatur-Jaworska, the elderly constitute a very diverse group and old age is not a homogeneous phase of life and it should be remembered while talking about old age. The research Forum $50+$ showed that the presence of the population of the elderly in the media is incommensurably small with regard to the number thereof. The approach in the media is stereotypical, showing an incapacitated senior or a cheerful senior in the middle of a physical activity. Meanwhile, the elderly constitute a very diverse group, since old age is not a homogeneous phase of life and it 
should be remembered while talking about old age. Also about the fact that the elderly are indispensable for the proper functioning of a society.

The changes that took place in the family functioning, with regard to reciprocity, duty and obligation towards family members lead to the increase in the need for 24-hour care institutions. In 2018, the number of citizens at the age of 60 years old and more amounted to 9501.4 thousand people and was by 214.8 thousand higher than in 2017. Due to the increase in the number of people, that belong to this age group, their percentage in the population of the whole country has gradually increased. In 2010, it amounted to $19.6 \%$, while in 2018 it reached the level of $24.8 \%$. At the end of 2018, stationary social welfare institutions had 118.9 thousand places, most of which were in nursing homes (82.8 thousand). In 2018, according to the Central Statistical Office of Poland, over 7 people of senior age per 1000 people of this age used stationary social welfare facilities. Most people benefited from this type of support in the Opole Voivodeship (10 people per 1000), and the least in the following voivodeships: Podlaskie, Lower Silesian, Kuyavian-Pomeranian and Lublin (6 people per 1000) (GUS 2020). In 2019, there were 875 nursing homes in Poland, according to the data of the Central Statistical Office. In the stationary social welfare institutions 112.5 thousand inhabitants resided and that was $0.5 \%$ less than the year before. Amongst all those inhabitants $72.7 \%$ of them are residents of nursing homes. The largest number of residents lived in institutions for the elderly ( $24.5 \%$ of the total number of inhabitants). The majority of residents of stationary social welfare institutions are elderly people, who are over 60 years old ( 72.5 thousand).

A new generation of the elderly is approaching. The generation that in the period of social changes after 1989 in Poland was entering adulthood, is aging. Those are persons who are often experienced by the changes and also able to find and take advantage of upcoming opportunities. More and more people among the population of the elder generation are educated and thus, with higher aspirations and expectations towards life, society, social or civil position. Currently, the older generation know their social position in parliamentary elections. Among the current and near future population of the elderly, there are many people who are lonely due to not starting a family. The number of childless people from this population is higher than before. 
Those are also Euro parents, whose children settled abroad and do not want to or cannot take their parents to their place, and at the same time they do not intend to come back. Therefore, it is necessary to create a new image of the older generation and new way of thinking of the elderly, not only in the framework of disability and the related care.

At this point, it is worth referring to the WHO's definition of health, which underlines three dimensions of a human: biological, social and mental. Many authors dealing with the issue of health (Frankl 1998, Popielski 1987, Dąbrowski 1974, Kropińska 2000) noticed the need for extending the definition with noetic dimension, where "human intentionality appears and thus, the strive for sense and value" (Frankl 1998, p. 9; Seredyńska 2000, p. 19). The noetic dimension characteristic only for humans covers thinking, attitudes, aspirations and life orientations (Seredyńska 2000, p. 18). Both, earlier and now, and certainly in the future, a holistic model of healthcare should be taken into consideration in care for the elderly in welfare institutions. In accordance with this model a human as a being apart from the biological dimension also has the mental and spiritual dimensions, which, in consequence, leads to attributing a special place to internal, spiritual abilities and strengths of a human. A dialogue with the ill/disabled/elderly, bigger sensitivity to a human and their suffering have an important place in the holistic thinking of a human (Seredyńska 2000, p. 16). Wellbeing determined by the sense of safety, stabilisation and clear rules of coexistence is important for the health of every human, also the elderly.

Therefore, in the view of new seniors there is a need to introduce new contents in educating carers and social workers so that carers can meet the expectations of future inhabitants of nursing homes (and indirectly, also their families).

In the view of welfare institutions, apart from system and educational solutions, there is the need to look at the institution's inhabitants in terms of care ethics. For N. Noddings care is expressed in taking actions. The basis of "worrying" about someone consists in concentrating on the needs, feelings and the ability to understand the person for whom we care. The caring person should have the ability to empathise with the person for whom they care. The acts of care are performed not only due to the situation of the person in need, 
but also in care for oneself. The proper relation of care also consists in taking care of the relation itself. In the ethics of care a huge emphasis is placed on specific relations and related obligations and not only on abstract rules not adjusted to specific circumstances. D. Bubeck pays attention to the important aspect of the lack of emotional engagement in care. It allows publicly providing care e.g. in healthcare or an aid institution (Waleszczyński 2012, pp. 151-155). N. Noddings notices that the relation with others is the point of reference for human existence. This aspect of social functioning should be also underlined in nursing homes. While preparing the personnel to work at this type of institution, it should be clearly specified that the criterion of moral assessment of an act does not constitute any universal principles, but specific reactions of persons whom such an act concerns. Each carer, nurse, social worker, human should know that when they face a moral choice it is not important to find a proper universal rule binding for all persons facing similar circumstances. Circumstances are never sufficiently similar, thus, it is necessary to approach everyone individually and with care. This type of postulate in the contemporary world seems to be obvious, thus, why is it so difficult to implement? The answer should be sought in education, or rather a lack thereof.

From the point of view of social policy, aging of the population is a problem related not only to social security, but also to the preparation of places in 24-hour care facilities. This problem requires systemic solutions related to the establishment of a climate, that allows the formation of such institutions, but also a revision of the approach to remunerations for the entire sector of aid professions.

\section{References}

Baggini J., Fosl (2010), Przybornik etyka. Kompendium metod i pojęć etycznych, Warsaw: Instytut Wydawniczy PAX. ISBN 9788321118703.

Dąbrowski K. (1974), Zdrowie psychiczne a wartości ludzkie, Warsaw: PTHP.

Doniec R. (2009), Relacje rodzinne a wyznaczniki partnerstwa w modelach i kulturze wychowawczej rodziny [in:] Truskolaska J. (ed.) Partnerstwo w rodzinie, Lublin: Wydawnictwo KUL. ISBN 9788373639294. 
De Barbro B. (1999), Struktura rodziny [in:] B. de Barbro (ed.), Wprowadzenie do systemowego rozumienia rodziny, Krakow: Wydaw. Uniwersytetu Jagiellońskiego. ISBN 8323311846.

Dyczewski L. (1994), Rodzina-Społeczeństwo-Państwo, Lublin: Wydawnictwo KUL. ISBN 8385291962.

Fabiś A., Chabior A., Wawrzyniak J.K. (2017), Ludzka starość. Wybrane zagadnienia gerontologii społecznej, Krakow: Oficyna Wydawnicza „Impuls”. ISBN 9788380952621.

Frankl V. E. (1998), Homo patiens, Warsaw: Instytut Wydawniczy Pax. ISBN 8321105246.

Guzy-Steinke H. (2014), Relacje rodziców i dzieci w kontekście wzajemności [in:] J. Brągiel, B. Górnicka (ed.) Rodzicielstwo w obliczu niepełnosprawności i zaniedbania, Opole: Wydawnictwo Uniwersytetu Opolskiego. ISBN 9788373955974.

Hałas E. (1998), Intymne wartości domu [in:] L. Dyczewski, D. Wadowski (eds.) Kultura dnia codziennego i świątecznego w rodzinie, Lublin: Redakcja Wydawnictw KUL. ISBN 8322806647.

Kalka J. (2016), Seniorzy a młodsze pokolenia - problemy życia codziennego. Komunikat $\mathrm{z}$ badań, CBOS no. 161, Warsaw.

Kołbik I., 1999, Lojalność rodzinna [in:] Wprowadzenie do systemowego rozumienia rodziny, ed. B. de Barbaro, Krakow: Wydaw. Uniwersytetu Jagiellońskiego. ISBN 8323311846.

Kowalewski J. T. (2006), Ludzie starzy w polskim społeczeństwie $\mathrm{w}$ pierwszych dekadach XXI wieku, Lodz: Wydawnictwo Uniwersytetu Łódzkiego. ISBN 8371719787.

Kropińska (2000), Przekonania zdrowotne. W poszukiwaniu perspektywy pedagogicznej, Bydgoszcz: Wydaw. Uczelniane WSP. ISBN 8370963234.

Nowak-Dziemianowicz M. (2002), Doświadczenia rodzinne w narracjach. Interpretacje sensów i znaczeń, Wroclaw: Wydaw. Uniwersytetu Wrocławskiego. ISBN 8322922728.

Popielski K., (1987), „Sens” i „wartość” życia jako kategorie antropologicznopsychologiczne [in:] Popielski K. (ed.), Człowiek pytanie otwarte: Studia z logoteorii i logoterapii, Lublin: Redakcja Wydawnictw KUL. ISBN 8300006672.

Popielski K., Wolicki M. (1987), Antropologiczno-filozoficzne podstawy analizy egzystencjalnej i niektóre jej aplikacje do teorii osobowości, [in:] Człowiek pytanie 
otwarte: Studia z logoteorii i logoterapii, Lublin: Redakcja Wydawnictw KUL. ISBN 8300006672.

Seredyńska D. (2010), Od koncepcji zdrowia do edukacji zdrowotnej [in:] M. Kuchcińska, E. Kościńska (eds.), Konteksty zdrowia i edukacji zdrowotnej, Bydgoszcz: Wydawnictwo Uniwersytetu Kazimierza Wielkiego. ISBN 9788370967611.

Szatur-Jaworska B. (2014), Uczestnictwo osób starszych w sferze publicznej, [in:] P. Szukalski, B. Szatur-Jaworska (eds.), Aktywne starzenie się - Przeciwdziałanie barierom, Lodz: Wydawnictwo Uniwersytetu Łódzkiego. ISBN 9788379690411.

Waleszczyński A. (2012), Pojęcie troski we współczesnej etyce, Studia Philosophiae Christianae 48/2. ISSN 0585-5470.

Wysocka E. (1998), Wybrane formy opieki i pomocy [in:] E. Marynowicz-Hetka, J.Piekarski,E.Cyrańska(eds.)Pedagogikaspołecznajakodyscyplinaakademicka.Stan perspektywy, Lodz: Wydaw. Uniwersytetu. ISBN 8371711751.

\section{Footnotes}

${ }^{1}$ In the Kuyavian-Pomeranian Voivodeship, as at 31 December 2018, there were 81 stationary social welfare institutions, including 49 nursing homes. 